\title{
The Shadow Lines: Interrogating the Great Divide
}

\author{
Dr. Pralayankar Kumar Singh \\ Lecturer in English \\ Government Polytechnic \\ Asthawan, Nalanda, Bihar, India \\ pralayankar.singh.kumar@gmail.com
}

\begin{abstract}
The article The Shadow Lines: Interrogating the Great Divide questions the concept of border and Partition- a solution to the problems of social unrest on religious grounds or political motivation. During the British Raj feeling of suspicion and hatred were planted in the heart and mind of millions of Indian people. The gulf of communal disharmony widened with time and this resulted in the partition of India and Pakistan in 1947. The ulterior motives of British Empire, the Congress Party and the Muslim League caused the partition of India. The then political leaders failed to resolve their difference over power-sharing. The ever widening gulf between the Hindus and the Muslims on communal issues was said to be the main cause of partition, though both the communities had a long history of peaceful co-existence for more than a thousand years. The Partition divided friends, families, lovers and neighbours. It led to the disintegration of human values, rootlessness and alienation.
\end{abstract}

Keywords: Partition, Riot, Communalism, Rootlessness, Alienation

One million dead, seventy five thousand women abducted and raped, and twelve million became refugees. Sexual humiliation traumatized women to such an extent that they 
preferred death to life. Snatching, murder and suicide were pervading either side of the border. Shriek resounded through the ambience. The horror of the partition had an indelible mark on the psyche of its victim.

Literature reflects society is a fact which has been widely acknowledged. In its corrective function literature depicts the ills of society in order to make the society realize its mistakes and to learn from it. And at the same time it also mirrors the virtues or good values of the society for the people to emulate.

During the British Raj feeling of suspicion and hatred were planted in the heart and mind of millions of Indian people. The gulf of communal disharmony widened with time and this resulted in the partition of India in 1947. The ulterior motives of British Empire, the Congress Party and the Muslim League caused the partition of India. The then political leaders failed to resolve their difference over power-sharing. The ever widening gulf between the Hindus and the Muslims on communal issues was said to be the main cause of partition, though both the communities had a long history of peaceful co-existence for more than a thousand years.

A nation is a combination of various elements such as territory, race, language, religion, culture, political and economic set-up. In Benedict Anderson view a nation is "an imagined community" (Anderson 15). Anderson says that the people despite being different, heterogeneous and mostly strangers to one another imagine themselves a community through various social, cultural and economic accounts found in newspaper, census reports, anthropological/ archaeological surveys, novels and other modern means of mass media. Thus, nation for him is an imaginative creation that unites people under a single territorial, cultural and administrative space. Eric Hobsbawn points out the element of "invention" and “social engineering" in making nations. 
India's concept of nationhood is based not only on territorial extent of its sovereignty but also on nationalistic sentiments and expressions which encompass India's ancient history as the birthplace of the Indus Valley Civilisation and Vedic Civilization as well as four major world religions- Hinduism, Budhism, Jainism and Sikhism. India's primeval idea of nation emphasizes moralistic and spiritual values like truth, righteousness, valour, education, spiritual power and altruism which have been propounded by the Vedic and Upanishadic seers and sages. It values multiculturalism or pluralism regarding language, ethnicity and religion. In modern age, also, the great lumainaries of India like Tagore, Aurobindo, Swami Vivekanand, Mahatma Gandhi, Radha Krishanan, Raja Rao and A.P.G. Kalam, to name a few, have interpreted these great civilisational values for their countrymen. Tagore adds great import to universal love, brotherhood and freedom whereas Gandhi underscores the value of truth, non-violence and cultural pluralism. Both oppose the idea of nation grounded in greed, violence and tyranny.

During the $18^{\text {th }}$ century, the rule of British East India Company consolidated in the Indian subcontinent and brought about socio-economic changes. This led to the rise of the Indian middle class. As a result, many pre-colonial socio-religious institutions and barriers were eroded. The increasing economic power of Indian business men and professionals beget the conflict of interest with the British Raj. Gradually consciousness developed among the native Indian elite. In the year 1885, the Indian National Congress was formed by A.O. Hume with a view to demand political liberalization, increased autonomy and social reforms. Its leaders held dialogue and debated with British administration in order to achieve their political goals. In 1906-07, the All India Muslim League was formed out of the suspicion of Muslims intellectuals and religious leaders that the Indian National congress was dominated by the Hindu membership and opinions. Perry Anderson too observes that the nationalism propagated by the Indian Congress Party was dominated early on by a Hindu ideology despite 
its secular aspirations that it openly claimed. Statics made in the mid1930s reveal that $97 \%$ of the Congress members were Hindus, and during that time Gandhi himself invoked Hindu imagery in his public speeches to gather new followers (Anderson 94). The suspicion was supported by eminent Muslim scholars and politicians Allama Iqbal, Muhammad Ali Jinnah and Liaquat Ali Khan. They came with the idea of separate nation for the Muslims and the Hindus. But there were other major Muslim leaders like Maulana Azad, Mukhtar Ahmed Ansari and most of Deobandi clerics who supported Mahatma Gandhi and opposed the idea of Muslim nationalism and separatism. But Indian nationalist Muslims failed to win the heart of Muslim masses whereas the Islamic nationalist Muslim League got popular political support. Consequently, India was divided on the basis of religion and a new country Pakistan appeared on the map. But India resorted to secularism and opted no official religion. Equality, liberty and all rights were conferred on the people of all religious groups irrespective of their caste and creed by Indian constitution.

The Partition of India has been one of the black chapters of its history. Partition and its aftermaths have drawn the attention of many sensitive authors especially the novelists of many prominent Indian languages. It has been widely accepted by many eminent historians that the Indian English literature has fairly represented Partition and its aftermaths. Ayesha Jalal and Sugatha Bose, and distinguished historians wrote in their book on South Asian history:

The colossal human tragedy of the partition and its continuing aftermath has been better conveyed by the more sensitive creative writers and artist- for example in Saddat Hasan Manto's short stories and Ritwik Ghatak's films- than by historians.

Khushwant Singh's Train to Pakistan (1956), Attia Housain's Sunlight on a Broken Column (1961), Manohar Malgaonkar's A Bend in the Ganges (1964), Raj Gill's The Rape (1974), 
Anita Desai's Clear Light of the Day (1980) and Bapsi Sidhawa's Ice Candy Man (1988), to name a few, are the prominent novels which depict partition with varied intensity.

The partition of India and its effect on the common mass of Indian sub-continent has been a great concern for Amitav Ghosh. It has found a place in one of his early novels The Shadow Lines. He writes that Partition has caused an irreparable life-long trauma. It has begotten great human displacement accompanied by gory and ghastly incidents of communal riots, atrocities and exploitation of all sorts on a grand level:

The political partition of India caused one of the great human convulsions of history. Never before or since have so many people exchanged their homes and countries so quickly. In the space of a few months about twelve million people moved between the new, truncated India and the two wings, East and West, of the newly created Pakistan. (Butalia 3)

The Shadow Lines as a Partition novel presents the aftermath of the Partition, especially concerned with the Partition on the Bengal border. The novel scoffs at the national leaders who believed that the Partition could solve the Hindu-Muslim animosity. Both Bengals have been historically, culturally, linguistically and geographically one. If Partition was done in order to gain freedom, the freedom proved a mirage. The Partition divided friends, families, lovers and neighbours. In the novel the narrator's family is spread over Dhaka, Calcutta and London. The family has narrator's grandmother, Mayadebi's elder sister, his parents, and their three sons, Jatin, Tridib and Robi. The narrator's family lives in Calcutta where his grandmother is the headmistress of a school.

Thamma thinks that the idea of a nation is created by shedding blood that makes "people forget they were born this or that, Muslim or Hindu, Bengali or Punjabi: they become a family born of the same pool of blood" (Ghosh 78). Thamma believes that the sacrifice made for one's own country is the greatest unifying force for the people. This idea is echoed 
by Mike, an Irishman, in the novel who asserts that to claim as an Indian, it is essential to kill an Englishman: "War against a common enemy unites, it ratifies boundaries and deepens the ideological and international oppositions necessary to mould an internally coherent national identity, it legitimizes the claim of the state to be the sole agent and authority of violence." (Kaul 279)

The grandmother strongly dislikes those Indians who live beyond his/her national border which is why she wants her uncle to return to India not because of familial feelings but because of nationalistic feelings. She wants him to die in his own country. For the same reasons, she thinks that Ila's stay in England is unjustified: "It took those people a long time to build that country, hundreds of years, years, and years of war and bloodshed. Everyone who lives there has earned his rights to be there with blood..." (Ghosh 77-78). Thamma thinks that a country needs borders to show a difference with and opposition to other countries, especially its neighbours. Before leaving for Dhaka she asks her son if she can witness the border between India and Pakistan. He answers that the border is not distinguishable like a long black line on a map showing green on one side and red on the other. Realizing the diaphanous nature of the border Thamma reconsiders her own idea of nationalism:

But if there aren't any trenches or anything, how are people to know? I mean, where's the difference then? And if there's no difference both sides will be the same; it'll be just like it used to be before, when we used to catch a train in Dhaka and get off in Calcutta the next day without anybody stopping us. What was it all for thenpartition and all the killing and everything- if there isn't in between? (151).

Thus the grandmother questions Partitions. She highlights the historical blunder committed by the elites of both sides. They parted those who shared culture, life style, memories and dreams. 
The Partition led to the disintegration of human values, rootlessness and alienation. The novel depicts the aftermaths of the partition on some of its characters including the grandmother, Saifuddin and Khalil. Once the border was drawn arbitrarily to separate India and Pakistan in 1947 people's identities were changed. Their nationality was at odds with their birth places. They became foreigners to their birth places. For example, in 1964, Thamma had some troubling experience at the airport when she was going to Dhaka, the place of her birth. She finds it difficult to understand how she can be an Indian citizen when her native town has become Pakistan "she liked things to be neat and in place and at that moment she had not been able to quite understand how her place of birth had come to be so messily at odds with her nationality" (155). She is now treated as a foreigner and is required to produce a visa. In her opinion, Dhaka will always be the home to come to and should, consequently, remain where she experiences the warmth of homecoming. While living in Calcutta in her one-room tenement, after the partition, the grandmother undergoes the alienation and homesickness. She feels nostalgic and is often reminded of her old, ancestral house and her parents.

Similarly for Jethamoshai, too, Calcutta has now become as much a 'foreign' city as Dhaka has become for Thamma. Jethamoshai has outrightly refused to leave his birth place though he has been warned against staying with strangers at the time of communal disharmony in Dhaka. He tries to convince his sons when they decide to move out of Dhaka:

'Once you start moving you never stop' he said, 'I don't believe in this India-Shindia. It's all very well. You're going away now, but suppose when you get there, they decide to draw another line somewhere? What will you do then? Where will you move to? No one will have you anywhere. As for me, I was born here and I'll die here" (215). 
The grandmother along with her sister returns by their car from Dhaka and the uncle leaves in a rickshaw. Little later Jethamoshai, Tridib and Khalid are killed by riotous Muslims. Behind the outbreak of such violence the involvement of political figures can't be denied. In a way politicians and political parties are the greatest beneficiaries of such violence. It serves their ends but proves lethal to common men and aggravates the communal harmony among different sects. The Shadow Lines discredits the States that fails to keep politics and religion separate.

Saifuddin, a Muslim from Bihar, is displaced by this Partition. He migrates to Dhaka in search of livelihood. He gets accommodation in grandmother's ancestral house. In her courtyard he sets up a workshop. With time he earns fame becomes one of the best mechanics in Dhaka. He, too, undergoes nostalgia and alienation. He remembers his birth place, Motihari. He urges Tridib to visit it. He tried his best to persuade his old father to come to Dhaka but it remained only a futile effort. He beseeched the grandmother to take Jethamoshai with her to India.

The novel also presents the pathetic conditions of the Muslims in India and the Hindu in East Pakistan who were displaced and compelled to migrate and lead a miserable life "the next few days the riots spread outwards from Khulna into the neighbouring town and districts and towards Dhaka. Soon Hindu refugees began to pour over the border into India" (228). After the Partition Thamma's ancestral house "had been occupied by Muslim refugees from India- mainly people who had gone across from Bihar and U.P.” (134)

The novel depicts how the borders of India and Pakistan have become sites of violenceviolence which cuts off communities, traumatizes common historical memory, and makes people refugees. Simultaneously it also insinuates that communal violence flaunts the connection and the continuity of social relations between communities that nation- states seek 
to efface. In the temporality of the communal violence in both places in which his cousin Tridib is killed in Dhaka, the narrator finds shared history and identity. Hence he says:

What had they felt,... Why they discovered that they had created not a separation, but a yet -undiscovered irony- the irony that killed Tridib the simple fact that there had never been a moment in the 4000-year-old history of that map when the places we know as Dhaka and Calcutta were more closely bound to each other than after they had drawn their lines-so closely that I, in Calcutta, had only to look into the mirror to be in Dhaka; a moment when each city was the inverted image of the other, looked into an irreversible symmetry by the line that was to set us free-our looking-glass border.(228)

Even during the communal riots in Dhaka and Calcutta when people were involved in loot, arson, rape and murder, there were many instances in East Pakistan where Muslims gave shelter to the Hindus at the cost of their lives and at the same time there were many Hindus protecting the Muslims. "But they were ordinary people, soon forgotten...not for them any Martyrs memorials or Eternal Flames" (230).

The Shadow Lines, thus, as a Partition novel questions the concept of border and Partition- a solution to the problems of social unrest on religious grounds or political motivation. It presents Partition as a trauma to thousands who had to migrate from their home or birth-place for not belonging to a certain religion.

It made thousands refugees, sans freedom and sans identity. The novel presents boundaries as shadow lines. In the last six decades which followed India's Independence, the official Indian historiography worked at blotting out the Partition violence from the memory of the masses to strengthen its secular ideals. 


\section{References}

Anderson, Benedict. Imagined Communities: Reflections on the Origin and Spread of Nationalism. London: Verso, 1983.

Anderson, Perry. The Indian Ideology. London: Verso, 2013.

Bose, Sugatha and Ayesha Jalal. Modern South Asia: History, Culture, Political Economy. London: Routldge, 1998.

Butalia, Urvashi. The Other Side of Silence: Voices from the Partition of India. 1998. Durham: Duke UP, 2000.

Ghosh, Amitav. The Shadow Lines. New Delhi: Ravi Dayal, 2001.

Kaul, Suvir. "Separation Anxiety: Growing up Inter/National in The Shadow Lines." Edu. ed 268

Bera, R. (2017). Decolonization of Mind in Amitav Ghosh's Writing: A Postcolonial Study of The Shadow Lines. IJOHMN (International Journal Online of Humanities), 3(2), 8. https://doi.org/10.24113/ijohmn.v3i2.26 